\title{
RESEARCH IN SP
}

The effect of prolonged repeated moderate intensity exercise on cytokine concentrations in adults

\author{
Autor(es): \\ Terink, R.; Bongers, C.W.G.; Witkamp, R.F.; Mensink, M.; Gunnewiek, \\ J.M.T.; Hopman, M.T.
}

Publicado por: Imprensa da Universidade de Coimbra

URL

persistente:

URI:http://hdl.handle.net/10316.2/44108

DOI:

DOI:https://doi.org/10.14195/2182-7087_ex2018_45

Accessed : $\quad$ 26-Apr-2023 15:31:20

A navegação consulta e descarregamento dos títulos inseridos nas Bibliotecas Digitais UC Digitalis, UC Pombalina e UC Impactum, pressupõem a aceitação plena e sem reservas dos Termos e Condições de Uso destas Bibliotecas Digitais, disponíveis em https://digitalis.uc.pt/pt-pt/termos.

Conforme exposto nos referidos Termos e Condições de Uso, o descarregamento de títulos de acesso restrito requer uma licença válida de autorização devendo o utilizador aceder ao(s) documento(s) a partir de um endereço de IP da instituição detentora da supramencionada licença.

Ao utilizador é apenas permitido o descarregamento para uso pessoal, pelo que o emprego do(s) título(s) descarregado(s) para outro fim, designadamente comercial, carece de autorização do respetivo autor ou editor da obra.

Na medida em que todas as obras da UC Digitalis se encontram protegidas pelo Código do Direito de Autor e Direitos Conexos e demais legislação aplicável, toda a cópia, parcial ou total, deste documento, nos casos em que é legalmente admitida, deverá conter ou fazer-se acompanhar por este aviso. 


\section{ANNALS OF RESEARCH IN SPORT AND PHYSICAL ACTIVITY}




\section{THE EFFECT OF PROLONGED REPEATED \\ MODERATE INTENSITY EXERCISE ON CYTOKINE CONCENTRATIONS IN ADULTS}

R. Terink1; C.W.G. Bongers²; R.F. Witkamp1; M. Mensink1; J.M.T. Gunnewiek³; M.T. Hopman²

KEYWORDS: Myokines, IL-6, TNF-alpha,

\section{PURPOSE}

Previous studies showed that cytokine concentrations are affected by the intensity and duration of one bout of exercise $(1,2)$. The cytokine responses after consecutive days of exercise have not been studied before, nor whether the responses differ between men and women. Therefore, the aim of this study was to asses cytokine responses after repeated bouts of exercise and compare those responses between men and women.

\section{METHODS}

50 male (58.9 \pm 9.9 years old) and 50 female $(50.9 \pm 11.2$ years old $)$ individuals were measured during four consecutive days of walking exercise. Participants walked 30, 40 or $50 \mathrm{~km}$, at a self-selected pace. Blood samples were collected one or two days prior to the start of the exercise (baseline) and at every walking day post-exercise. Blood samples were analysed for IL-6, IL-8, IL-10, IL-1beta and TNF-alpha concentrations.

\footnotetext{
1 Wageningen University \& Research, Division of Human Nutrition.

2 Radboud University Nijmegen, department of Physiology.

${ }^{3}$ Clinical Chemistry and Haematology Laboratory, Gelderse Vallei Hospital (ZGV).

Email: rieneke.terink@wur.nl
} 


\section{RESULTS}

All cytokine concentrations increased from baseline to post-exercise at day 1 ( $p<$ 0.001). These concentrations significantly decreased from day 1 to day 2 ( $p<0.001$ ), except for IL-1beta. IL-10 was higher in men than in women after the $1^{\text {st }}$ day of exercise, IL-6 was higher in men after the $2^{\text {nd }}$ day, and IL-1beta and TNF-alpha were higher in men during all days.

\section{CONCLUSION}

The exercise-induced change in cytokines after day 1, attenuated on subsequent days. Men and women showed different baseline levels and similar exercise responses. These results suggest that muscles adapt rapidly to this type of exercise.

\section{ACKNOWLEDGMENTS}

This study was part of the EAT2MOVE project and supported by a grant from the Province of Gelderland, proposal PS2014-49.

\section{SPECIAL THANKS}

We would like to acknowledge Nhien Ly for her work as analyst. She analyzed the cytokine concentrations.

\section{AUTHORSHIPS}

The study was designed by R. Terink, C.W.G. Bongers, M.T. Hopman, and M.R. Mensink; data were collected and analyzed by R. Terink and C.W.G. Bongers; data interpretation and manuscript preparation were undertaken by R. Terink, C.W.G. Bongers, M.T. Hopman, R.F. Witkamp, M.R. Mensink, and J.M.T. Klein Gunnewiek. All authors approved the final version of the paper. 


\section{DECLARATION}

We declare that the results of this study are presented clearly, honestly, and without fabrication, falsification, or inappropriate data manipulation.

\section{REFERENCES}

1. Pedersen BK, Toft AD. Effects of exercise on lymphocytes and cytokines. British journal of sports medicine. $2000 ; 34^{(4)}: 246-51$.

2. Pedersen BK. Special feature for the Olympics: effects of exercise on the immune system: exercise and cytokines. Immunology and cell biology. 2000;78(5):532-5. 